\section{PELATIHAN ENGLISH CONVERSATION BAGI TENAGA PENDIDIK DI UNIVERSITAS NAHDLATUL ULAMA PURWOKERTO}

M. Happy Nur Tsani', Asfi Aniuranti², Asep Budiman ${ }^{3}$

\author{
1,2,3 Pendidikan Bahasa Inggris, \\ Universitas Nahdlatul Ulama \\ Purwokerto
}

"M. Happy Nur Tsani Email: mhappynur2@gmail.com

\begin{abstract}
English as an international language has a vital role in the development of an institution, especially in communication. English Conversation training for academic staff at UNU Purwokerto was held to train and get used to using English on campus to achieve the goal of becoming a world-class university. The training is intensive with the lecturing methods, question and answer, discussion, problemsolving, practice, and evaluation. Participants are very participatory in training. From the three practice activities, the average speaking ability of the participants increased in each practice. The average value in the first practice was 67 . Then, the average increased to 74 in the second practice and 80 in the last practice. There is about a $19.40 \%$ increase from initial practice to last practice. In addition, the results of the questionnaire also showed a positive response from the participants. The highest percentage for each item in the questionnaire is on a scale of 4 and 5.

Keywords: English Conversation; Educational Staff; Basic English
\end{abstract}

\begin{abstract}
Abstrak
Bahasa Inggris sebagai Bahasa Internasional mempunyai peran vital dalam perkembangan suatu instansi khususnya di bidang komunikasi. Pelatihan English Conversation untuk tenaga kependidikan UNU Purwokerto dilaksanakan untuk melatih dan membiasakan penggunaan Bahasa Inggris di kampus demi tercapainya tujuan menjadi world class university. Pelatihan dilaksanakan secara intensif dengan metode ceramah, tanya jawab, diskusi, pemecahan masalah, praktik, dan evaluasi. Peserta sangat partisipatif dalam pelatihan. Dari tiga kali kegiatan parktik, rerata nilai kemampuan berbicara peserta mengalami peningkatan di masing-masing praktik. Nilai rerata di praktik pertama sebesar 67 . Kemudian, rerata meningkat menjadi 74 pada praktik kedua, dan kembali meningkat menjadi 80 di praktik terakhir. Ada sekitar 19,40\% peningkatan dari praktik awal ke praktik terakhir. Selain itu, hasil angket juga menunjukkan adanya respon positif dari para peserta. Prosentase tertinggi untuk masing-masing item dalam angket berada pada pada skala 4 dan 5 .

Kata Kunci: English Conversation; Tenaga Kependidikan; Basic English
\end{abstract}


Pelatihan English Conversation Bagi Tenaga Pendidik di Universitas Nahdlatul Ulama Purwokerto

M. Happy Nur Tsani, Asfi Aniuranti, Asep Budiman

Vol. 1, No. 2, Agustus 2021 hal. 156-164

DOI Artikel : 10.46306/jub.v1i2.31

\section{PENDAHULUAN}

Di era globalisasi, seorang dituntut untuk mampu bersaing dengan bangsa lain. Hal tersebut tidak akan berjalan baik apabila kemampuan berbahasa asing yang ia miliki minim (Lie, 20I7). Dari banyaknya bahasa yang ada, bahasa Inggris menjadi hal wajib untuk dipelajari. Bahasa Inggris merupakan bahasa internasional yang digunakan dalam berbagai bidang. Mulai dari ekonomi, politik, bisnis, hingga teknologi. Comrie (2009) menyebutkan bahwa bahasa Inggris merupakan basantara dari banyak kegiatan pembelajaran khususnya pada bidang ilmiah dan teknik. Reddy (2016) menambahkan bahwa bahasa Inggris memegang peranan penting dalam kehidupan sehari-hari, dan terdapat kegunaan yang luar biasa dari bahasa Inggris dalam kehidupan modern. Patel \& Jain (2008) juga menjelaskan bahwa bahasa tidak hanya berperan sebagai alat komunikasi, tetapi juga dapat mempermudah beradaptasi dengan lingkungan dan pekerjaan. Dengan menguasai bahasa Inggris, seseorang selangkah lebih maju untuk meraih tujuan. Entah itu untuk karier, kelangsungan bisnis, atau menambah koneksi. Inilah mengapa kemampuan bahasa Inggris menjadi salah satu syarat utama untuk bersaing di era globalisasi.

Pentingnya bahasa Inggris dalam kegiatan di berbagai bidang mengharuskan banyak pihak untuk memperlajari bahasa Inggris. Salah satunya adalah para tenaga kependidikan di Universitas Nahdlatul Ulama Purwokerto yang memiliki cita-cita untuk menjadi kampus yang diakui pada taraf internasional dan telah memiliki beberapa mahasiswa asing. Setiap hari Sabtu, seluruh civitas akademika diwajibkan berkomunikasi dengan Bahasa Inggris (English Day), namun masih banyak yang belum mau melaksanakan kegiatan tersebut. Banyak faktor yang menjadi pemicu dan salah satunya adalah rendahnya kemampuan berbicara. Bailey (2005) menyebutkan dalam kajiannya bahwa umumnya masih banyak tenaga kependidikan yang belum memiliki kemampuan berbicara dalam Bahasa Inggris.

Berdasarkan latar belakang tersebut, tim PKM menilai bahwa kemampuan berbicara dalam bahasa Inggris yang dimiliki para staff perlu untuk ditingkatkan dan salah satu hal yang dapat ditempuh adalah penyelenggaraan pelatihan English Conversation. Secara sederhana, English conversation sendiri dapat didefinisikan sebagai proses pelatihan penguasaan Bahasa Inggris yang difokuskan ada penguasaan keterampilan komunikasi (Nation, 2017). Pelatihan English conversation menjadi hal yang dibutuhkan untuk memahami dasar-dasar berkomunikasi dalam Bahasa Inggris (Muslim, 2009). Tujuan pelatihan ini sendiri untuk menambah keterampilan berkomunikasi dan berinteraksi dengan menggunakan Bahasa Inggris bagi tenaga kependidikan di Universitas Nahdlatul Ulama Purwokerto. Dengan penguasaan kemampuan berbicara dalam bahasa Inggris, Universitas Nahdlatul Ulama Purwokerto dapat selangkah lebih dekat dengan cita-cita menjadi kampus yang dapat diakui di level internasional atau paling tidak memberi pelayanan yang baik kepada mahasiswa asing yang ada.

\section{METODE PENGABDIAN}

Metode kegiatan yang dilakukan dalam Program Kemitraan Masyarakan (PKM) ini adalah:

I. Ceramah

Beberapa tujuan dari ceramah dalam PKM ini adalah:

a. Informatif

PKM ini memberikan informasi kepada para peserta pelatihan mengenai dasar-dasar komunikasi dalam Bahasa Inggris (Budiman, 2003).

b. Persuasif

Selain memberikan informasi kepada para peserta pelatihan, PKM ini juga bertujuan untuk mengajak para peserta menggunakan Bahasa Inggris dalam percakapan sehari-hari di Universitas Nahdlatul Ulama Purwokerto.

c. Argumentatif 
Pelatihan English Conversation Bagi Tenaga Pendidik di Universitas Nahdlatul Ulama Purwokerto

M. Happy Nur Tsani, Asfi Aniuranti, Asep Budiman

Vol. 1, No. 2, Agustus 2021 hal. 156-164

DOI Artikel : 10.46306/jub.v1i2.31

PKM ini juga bertujuan untuk menyampaikan sebuah topik yang bisa dipahami para pendengar mengenai suatu hal, dengan cara menyampaikan argumen dan contoh yang bisa dipahami kaitannya dalam percakapan dasar Bahasa Inggris di tempat kerja.

d. Rekreatif

PKM ini memiliki tujuan menghibur atau membuat gembira para peserta pendengar agar selain mendapat ilmu mereka juga merasa puas dan bahagia.

e. Naratif

PKM ini juga menerapkan pendekatan student-centered learning dan active learning di mana peserta pelatihan lebih partisipatif dalam belajar dan menceritakan suatu hal kepada peserta yang lainnya maupun narasumber dengan menggunakan Bahasa Inggris.

2. Diskusi dan Tanya Jawab

Pelatihan yang efektif dan efisien salah satunya adalah adanya pembahasan oleh lebih dari satu orang

(Richards \& Long, 1986). Adapun tujuan penggunaan metode diskusi dalam pelatihan ini adalah:

a. Memberikan kesempatan kepada semua peserta untuk berpikir secara demokratis

b. Memberikan kesempatan kepada semua peserta untuk memecahkan masalah secara demokratis

c. Meningkatkan partisipasi peserta pelatihan dalam pemahaman teori dan praktik basic English Conversation.

Dalam kegiatan diskusi peserta juga cukup aktif melakukan tanya jawab. Metode ini merupakan merupakan metode yang paling sering digunakan dalam penyampaian konsep basic English Conversation (Pasaribu, 2007).

3. Praktik

Setelah pemberian teori-teori dasar yang dibutuhkan para peserta pelatihan untuk melakukan kegitan percakapan dalam bahasa Inggris seperti strategi ketika berbica dan ekspresi yang dibutuhkan dalam percakapan, para peserta diberi kesempatan untuk melakukan praktik percakapan baik secara individu maupun kelompok. Kegitan praktik merupakan kegiatan yang paling tepat untuk meningkatkan kemampuan berbicara para peserta pelatihan. Menurut Paisley (202I), latihan percakapan memungkinkan pembelajar bahasa untuk mengasimilasi pengetahuan yang mereka peroleh, mengintegrasikan berbagai keterampilan kognitif sekaligus untuk menghasilkan komunikasi lisan. Berdarakan studi dari Hopman \& MacDonald dalam Paisley (202I), para pembelajar yang mempelajari bahasa melalui kegiatan parktik cenderung mengalami kemajuan yang lebih baik dari pada mereka yang hanya belajar melalui pemahaman tanpa adanya kegiatan praktik.

4. Evaluasi

Tim melakukan kegiatan evaluasi sebagai upaya untuk menjaga kualitas pelatalihan yang diselenggarakan. Kegiatan evaluasi dilakukan oleh tim setelah seluruh rangkaian acara dilaksanakan. Menurut Arikunto (2007), Evaluasi berarti pengumpulan kenyataan secara sistematis untuk menetapkan apakah dalam kenyataannya terjadi perubahan dalam diri siswa dan menetapkan sejauh mana tingkat perubahan dalam diri pribadi siswa.

\section{PELAKSANAAN DAN PEMBAHASAN}

\section{Pelaksanaan}

Pelaksanaan kegiatan tergambar pada jadwal di bawah ini.

\begin{tabular}{|l|l|l|}
\hline \multicolumn{2}{|c|}{ Table I. Jadwal Kegiatan PKM } \\
\hline $08.00-08.30$ & $\begin{array}{l}\text { Pembukaan } \\
\text { Perkenalan dan Ice Breaking } \\
\text { (Analisis Masalah } \\
\text { (diskusi dengan peserta mengenai permasalahan dalam } \\
\text { komunikasi Bahasa Inggris)) }\end{array}$ & M. Happy Nur Tsani \\
\hline $08.30-09.30$ & Speaking Strategies (Overview) & Asfi Aniuranti \\
\hline $09.30-10.30$ & $\begin{array}{l}\text { Introduction } \\
\text { Greetings }\end{array}$ & Asep Budiman \\
\hline
\end{tabular}


Pelatihan English Conversation Bagi Tenaga Pendidik di Universitas Nahdlatul Ulama Purwokerto

M. Happy Nur Tsani, Asfi Aniuranti, Asep Budiman

Vol. 1, No. 2, Agustus 2021 hal. 156-164

DOI Artikel : 10.46306/jub.v1i2.31

\begin{tabular}{|l|l|l|}
\hline & Basic Daily Conversation / Expressions & \\
\hline $10.30-12.30$ & Simulasi dan Praktik & M. Happy Nur Tsani \\
\hline 12.30-13.00 & Penutup (Testimoni) & Tim \\
\hline
\end{tabular}

Berdasarkan tabel di atas, dapat dilihat bahwa secara keseluruhan kegiatan pelatihan terdiri dari beberapa tahapan, yaitu diskusi analisis masalah, penyampaian strategi dalam berbicara bahasa Inggris, pemberian teori mengenai bagaimana berkenalan dalama bahasa Inggris, bagaimana menyapa dalam bahasa Inggris dan dasar percakapan dalam bahasa Inggris, pelaksanaan praktik, dan pengisian angket di bagian penutup. Berikut uraian singkat mengenai masing-masing tahapan.

Pada tahapan analisis masalah, banyak peserta yang merasa kurang percaya diri, 'grogi', sehingga tidak dapat mempraktekan English Conversation dengan maksimal. Sebagian besar dari mereka merasa khawatir melakukan kesalahan ketika berbicara bahasa Inggris. Terdapat juga peserta yang mengaku khawatir dengan kemampuan gramatikanya ketika bahasa Inggris. Kegiatan diskusi awal ini mengutkan tim bahwa pelatihan English Conversation memang masih sangat diperlukan.

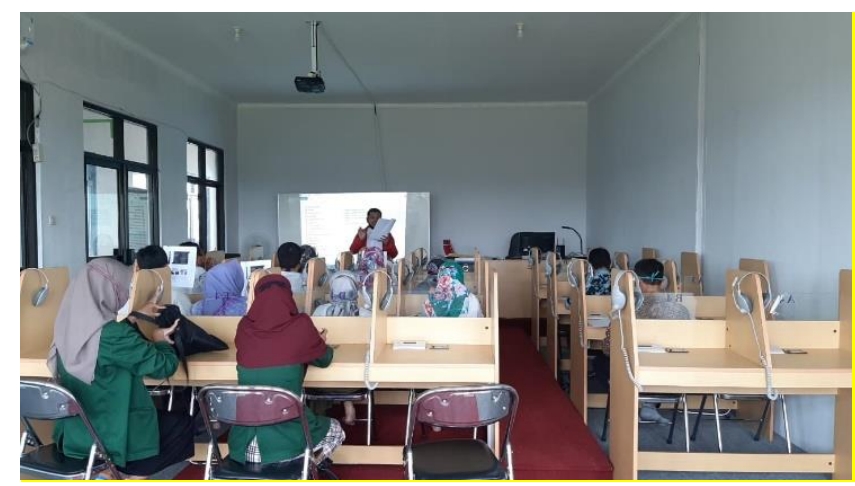

Gambar I: Tim berdiskusi dengan peserta mengenai permasalahan berkomunikasi dalam bahasa Inggris

Tahapan selanjutnya adalah pemberian teori mengenai berbagai strategi yang dapat digunakan oleh peserta ketika sedang berbicara dalam bahasa Inggris. Terdapat beberapa jenis speaking strategies yang didiskusikan diantaranya adalah using fillers, doing self repair, using mime, paraphrasing, using approximation, dan leaving some messages unfinished. Pembekalan mengenai strategi tersebut akan membantu peserta untuk lebih percaya diri dan tidak terlalu khawatir ketika berbicara sebab terdapat strategi khusus yang memungkinkan untuk dilakukan.

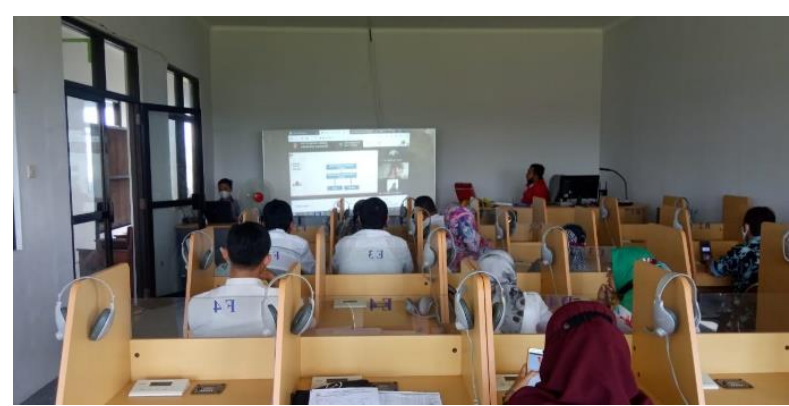

Gambar 2: Penyampaian Materi speaking strategies

Tahapan selanjutnya yaitu penjelasan teori tentang Introduction, Greetings dan Basic Daily Conversation / Expressions. Pada tahapan ini peserta diberi teori tentang bagaimana memperkenalkan diri baik secara formal dan informal. Setelah materi perkenalan, peserta juga dibekali dengan ungkapan 
Pelatihan English Conversation Bagi Tenaga Pendidik di Universitas Nahdlatul Ulama Purwokerto

M. Happy Nur Tsani, Asfi Aniuranti, Asep Budiman

Vol. 1, No. 2, Agustus 2021 hal. 156-164

DOI Artikel : 10.46306/jub.v1i2.31

salam dalam bahasa Inggris. Diakhir sesi ini peserta juga diberi materi dasar ungkapan yang biasa diucapkan setiap hari dengan tujuan untuk bekal praktik berbicara bahasa Inggris setiap harinya.

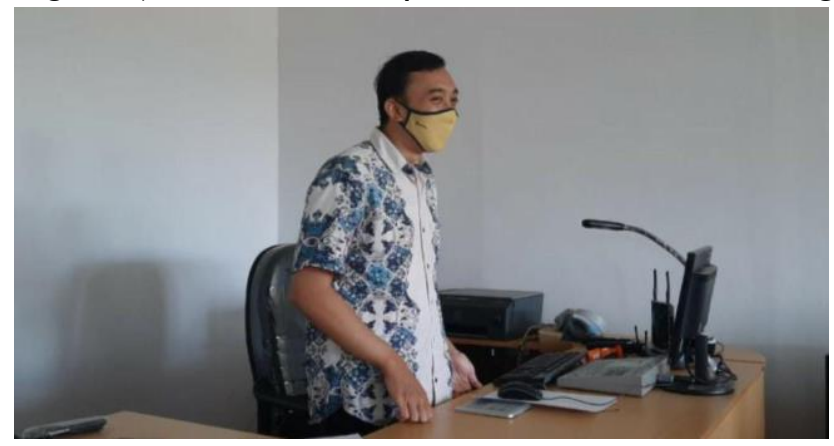

Gambar 3: Penjelasan teori tentang Introduction, Greetings dan Basic Daily Conversation I Expressions.

Setelah pemberikan berbagai teori, peserta diminta untuk melaksanakan kegiatan praktik individu dan kelompok. Sebelum peserta mempraktikan langsung, peserta diberikan simulasi langsung oleh mahasiswa prodi Pendidikan Bahasa Inggris, simulasi ini diberikan untuk memberikan gambaran yang jelas bagaimana mempraktekan bahasa Inggris dengan baik dan benar. Setelah simulasi, peserta secara beruturan mempraktekan langsung di depan kelas. Secara keseluruhan para peserta menjadi lebih berani mempraktikan English Conversation. Nilai rerata dari tiga kali kegiatan praktik juga mengalami peningkatan. Pada saat awal pelatihan menunjukan rata-rata 67, namun setelah akhir pelatihan mengalami hasil yang cukup signifikan menjadi 80 . Terdapat peningkatan rerata nilai di ketiga praktik yang dilakukan dan dari praktik awal ke akhir ada peningkatan sebesar 19,40\%. Berikut hasil assessment pelatihan English conversation.

Table 2. Hasil Assesment kegiatan Pelatihan English Conversation

\begin{tabular}{|c|c|c|c|c|}
\hline No & Name & Praktik I & Praktik 2 & Praktik 3 \\
\hline I. & Burhanudin & 65 & 73 & 81 \\
\hline 2. & Aditya Yudhit Irfianto & 63 & 70 & 75 \\
\hline 3. & Muhammad Zaky & 68 & 75 & 79 \\
\hline 4. & Lady Itsnia Ulinna'mah & 68 & 76 & 82 \\
\hline 5. & Wahyu Maulana Endris & 65 & 73 & 81 \\
\hline 6. & Irfan Mei Riandika & 63 & 70 & 75 \\
\hline 7. & Rosmilia Herawati & 70 & 75 & 80 \\
\hline 8. & Lutfiana & 75 & 80 & 82 \\
\hline 9. & Prasetya Risa Kartika & 66 & 75 & 82 \\
\hline 10. & Septian Hendra Harismono & 65 & 72 & 78 \\
\hline II. & Riska Hanifah & 66,8 & 73,9 & 79 \\
\hline 12. & Rosiana Dwi Nuraeni & 65 & 73 & 80 \\
\hline \multicolumn{2}{|r|}{ Rata-rata } & 67 & 74 & 80 \\
\hline
\end{tabular}

Setelah program PKM tersebut selesai dilaksanakan, tim pengabdi akan melakukan monitoring dan evaluasi kepada mitra. Karena dalam hal ini mitra masih membutuhkan masukan-masukan sebagai bahan evaluasi dalam proses pembiasaan English Conversation. Peserta diminta mengisi angket mengenaik kegiatan pelatihan yang telah dilaksanakan. Angket yang digunakan merupakan jenis angket tertutup yang terdiri dari lima item dengan lima pilihan, yaitu Sangat Setuju (SS), Setuju (S), Netral (N), Tidak Setuju (TS) dan Sangat Tidak Setuju (STS). Berikut rincian hasil angket yang telah diisi oleh peserta pelatihan.

Table 3. Persepsi Peserta terhadap kegiatan Pelatihan English Conversation

$\begin{array}{llllll}\text { Pertanyaan } & \text { SS } & \text { S } & \text { N } & \text { TS } & \text { STS }\end{array}$


Pelatihan English Conversation Bagi Tenaga Pendidik di Universitas Nahdlatul Ulama Purwokerto

M. Happy Nur Tsani, Asfi Aniuranti, Asep Budiman

Vol. 1, No. 2, Agustus 2021 hal. 156-164

DOI Artikel : 10.46306/jub.v1i2.31

\begin{tabular}{lccc}
\hline $\begin{array}{l}\text { Kemampuan komunikasi dalam bahasa Inggris penting bagi } \\
\text { Staff/Tendik UNU Purwokerto }\end{array}$ & $58,3 \%$ & $33.3 \%$ & $8.3 \%$ \\
\hline $\begin{array}{l}\text { Pelatihan English conversation bermanfaat bagi Staff/Tendik } \\
\text { UNU Purwokerto }\end{array}$ & $50 \%$ & $50 \%$ & \\
\hline Materi yang disampaikan dapat dipahami & $50 \%$ & $41.7 \%$ & $8.3 \%$ \\
\hline Kegiatan praktek yang dilakukan sangat membantu & $50 \%$ & $50 \%$ & \\
\hline Pelatihan semacam ini perlu diadakan lagi & $41.7 \%$ & $50 \%$ & $8.3 \%$ \\
\hline
\end{tabular}

Dari hasil angket diatas, dapat ditarik kesimpulan bahwa respon peserta sangatlah positif terhadap rangkaian kegiatan pelatihan yang telah dilaksanakan. Prosentase tertinggi masih berada pada tanggapan positif yaitu sangat setuju dan setuju.
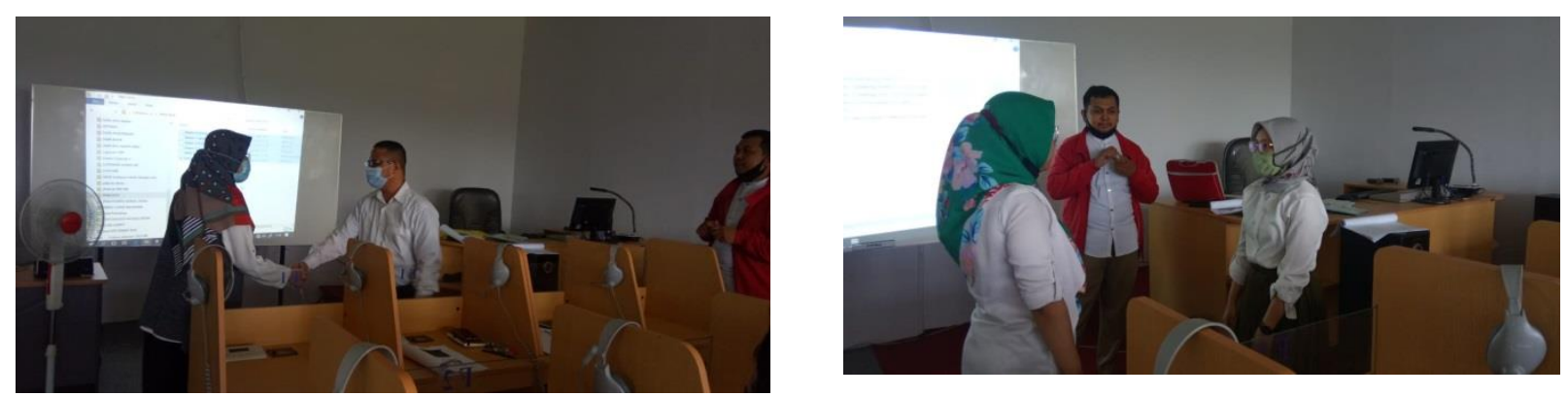

Gambar 4: Peserta Praktik English Conversation Secara Langsung

\section{Pembahasan}

Pelatihan English Conversation diawali dengan perkenalan singkat menggunakan bahasa Inggris dan dilanjutkan dengan Ice Breaking. Pada saat sesi perkenalan, terlihat mayoritas peserta beraut muka gugup. Namun dengan adanya Ice Breaking pada sesi berikutnya, peserta menjadi lebih rileks. Itulah mengapa pelatihan ini menyisipkan beberapa Ice Breaking untuk mencairkan suasana, menurunkan tingkat kecemasan, dan mengembalikan fokus peserta. Hal ini sejalan dengan penelitian yang dilakukan oleh Chao dan Fan (2020) selama 10 minggu bahwa Ice Breaking dapat mengurangi tingkat kecemasan siswa dalam belajar bahasa asing.

Kemampuan berbicara atau berkomunikasi dalam bahasa Inggris sangat erat kaitannya dengan rasa percaya diri. Menurut (Brown, 2000), terdapat beberapa faktor yang mempengaruhi kinerja speaking seperti; kecemasan, gugup, dan tidak percaya diri. Dengan adanya diskusi dan analisis permasalahan dalam berkomunikasi dalam bahasa Inggris, peserta menjadi lebih percaya diri untuk mempraktekan bahasa Inggris dalam kehidupan sehari-hari.

Strategi belajar menjadi salah satu faktor yang mempengaruhi peningkatan kemampuan peserta. Menurut Hismanoglu (2000) strategi belajar bahasa mencakup perilaku dan pikiran yang sengaja digunakan pembelajar selama belajar untuk membantu mereka memahami, belajar, atau mengingat informasi baru. Dengan adanya metode simulasi dan praktek menjadikan peserta lebih percaya diri dalam kemampuan bahasa Inggris.

Instruktur dalam pelatihan ini tidak bersifat menggurui namun lebih berperan sebagai fasilitator untuk belajar bahasa Inggris. Diinisiasi dengan analisis masalah termasuk diskusi di dalamnya mengenai permasalahan umum dalam berbahasa Inggris, peserta secara aktif mengungkapkan masalah riil yang mereka hadapi ketika menggunakan bahasa Inggris. Beberapa peserta menanggapi dengan solusi yang mereka lakukan saat menghadapi masalah tersebut. Selanjutnya, instruktur memberi penguatan terhadap masalah yang peserta hadapi dan cara mengatasinya. Dengan demikian, kelas menjadi lebih 
Pelatihan English Conversation Bagi Tenaga Pendidik di Universitas Nahdlatul Ulama Purwokerto

M. Happy Nur Tsani, Asfi Aniuranti, Asep Budiman

Vol. 1, No. 2, Agustus 2021 hal. 156-164

DOI Artikel : 10.46306/jub.v1i2.31

aktif, partisipatif, dan berpusat pada peserta pelatihan. Pembelajaran dengan pendekatan studentcentered learning (SCL) diyakini lebih bermakna bagi peserta dibandingkan dengan teacher-centered learning (TCL) khususnya dalam pembelajaran basic English Conversation. Benlahcene dkk., (2020) mengungkapkan bahwa peserta didik menunjukkan respon positif terhadap SCL karena dapat mendukung peningkatan kemampuan kognitif, afektif, dan metakognitif peserta didik.

Pembawaan materi terkait Speaking Strategies, Introduction, Greetings, dan Basic Daily Conversation dikemas dengan sajian yang menarik dengan suguhan video memungkinkan peserta pelatihan merasa nyaman dan termotivasi dalam belajar. Setiap materi disajikan dengan metode PPP singkat (Presentation, Practice, Production) membuat peserta tidak hanya mendengarkan namun langsung mempraktikan apa yang mereka dengarkan dengan pasangan yang selalu berubah-ubah. Hal ini sejalan dengan penelitian yang telah dilakukan oleh Ihsan (2020) bahwa PPP efektif meningkatkan kemampuan berbicara bahasa Inggris peserta didik. Di samping itu, beberapa peserta pelatihan juga memberikan respon positif terhadap PPP. Salah satu peserta berinisial (W) mengatakan:

"Materi Basic English Daily Conversation sangat penting untuk dipelajari, namun yang lebih penting lagi adalah dipraktikan. Dengan metode PPP ini saya tidak hanya memperhatikan bahasa, namun juga mempraktikannya".

(R) juga berpendapat:

"Dulu saya belajar bahasa Inggris di kelas kebanyakan hanya memperhatikan saja, besoknya lupa. Namun di sini kami bukan hanya memperhatikan, tapi langsung praktik, sehingga tidak cepat lupa".

Setelah pemaparan materi selesai, simulasi dan praktik kombinasi keseluruhan materi dilakukan di akhir kegiatan. Hal ini dilakukan sebagai langkah evaluasi kegiatan untuk mengukur tingkat pemahaman dan kemampuan peserta pelatihan. Tes singkat percakapan bahasa Inggris yang mengandung materi Introduction, Greetings, dan Basic Daily Conversation diselenggarakan dengan pendampingan oleh instruktur. Evaluasi penting dilakukan agar nanti di akhir ada penguatan terhadap materi yang mayoritas peserta pelatihan masih belum memahami dengan sempurna. Crocker (2019) menegaskan bahwa evaluasi dalam sistem pendidikan dan pelatihan itu sangat penting untuk dilakukan untuk mencapai output yang lebih baik. Evaluasi kegiatan pelatihan ini juga mendapatkan respon yang positif dari peserta. Salah satu peserta (B) mengatakan:

"Evaluasi kegiatan tidak terasa sebagai evaluasi, kami merasa seperti praktik biasa dan lebih rileks".

(S) juga menambahkan:

"Walaupun evaluasi dilaksanakan dengan cara yang enjoyable, esensi dari setiap indikator materi yang diajarkan tetap diperhatikan, dicatat, dan diberi masukan".

(L) mengatakan:

"Kami lebih percaya diri dalam praktik di evaluasi ini karena instruktur memperkenankan kami untuk berkonsultasi terkait percakapan yang kami buat dan disimulasikan sebelumnya".

Menilik hasil penilaian praktik English Conversation, rata-rata peserta pelatihan mengalami kemajuan dalam setiap praktiknya. Kemajuan dalam kemampuan percakapan ini tentunya tidak lepas dari pendekatan pembelajaran, metode penyampaian, sajian materi yang menarik, serta evaluasi yang komprehensif. Tahap perencanaan pelatihan, dalam pelatihan, serta pasca pelatihan sebagai bentuk follow-up action harus dikonsep secara matang demi terwujudnya pelatihan yang bermakna (Gurley, 2018). 
Pelatihan English Conversation Bagi Tenaga Pendidik di Universitas Nahdlatul Ulama Purwokerto

M. Happy Nur Tsani, Asfi Aniuranti, Asep Budiman

Vol. 1, No. 2, Agustus 2021 hal. 156-164

DOI Artikel : 10.46306/jub.v1i2.31

Peningkatan kemampuan peserta dapat dilihat dari rerata nilai di ketiga praktik yang dilakukan dari awal hingga akhir sebesar 19,40\%. Keberhasilan ini tidak terlepas dari adanya motivasi dan antusiasme peserta untuk meningkatkan kemampuan bahasa Inggris. Hal ini senada dengan pendapat Winardi (2007) yang menyampaikan bahwa motivasi merupakan hasil sejumlah proses yang bersifat internal atau eksternal bagi seorang individu, yang menyebabkan timbulnya sikap entutiasme dan persistensi dalam hal melaksanakan kegiatan-kegiatan tertentu. Disela-sela kesibukannya sebagai tenaga kependidikan, peserta cukup semangat mengikuti pelatihan dari awal hingga akhir. Data dari angket yang diberikan di akhir kegiatan menunjukan bahwa respon peserta sangatlah positif terhadap rangkaian kegiatan pelatihan yang telah dilaksanakan. Hal ini menunjukkan bahwa kegiatan pelatihan yang dilakukan memiliki dampak yang positif bagi peserta pelatihan. Menurut Simamora (2004) Evaluasi membutuhkan adanya penilaian terhadap dampak program pelatihan pada perilaku dan sikap dalam jangka pendek dan jangka panjang.

\section{KESIMPULAN DAN SARAN \\ Kesimpulan}

Kemampuan mempraktikan English Conversation merupakan kemampuan yang bisa dicapai melalui kegiatan pelatihan. Upaya Tenga Kependidikan untuk bisa meningkatkan kemampuan English Conversation melalui pelatihan ini cukup signifikan. Dari tiga kali kegiatan parktik, rerata nilai kemampuan berbicara peserta mengalami peningkatan di masing-masing parktik. Nilai rerata di parktik pertama sebesar 67. Kemudian, rerata meningkat menjadi 74 pada praktik kedua, dan kembali meningkat menjadi 80 di praktik terakhir. Ada sekitar 19,40\% peningkatan dari praktik awal ke praktik terakhir. Selain itu, hasil angket juga menunjukkan adanya respon positif dari para peserta. Prosentase tertinggi untuk masing-masing item dalam angket berada pada pada skala 4 dan 5 . Dilihat dari antusiasme, para peserta pelatihan juga terlihat begitu antusias selama mengikuti kegiatan.

\section{Saran}

Ada dua saran yang dapat kami rekomendasikan. Pertama, untuk pelatihan yang efektif, diharapkan ketersediaan peralatan audio visual yang memadai. Kedua, durasi pelatihan yang ditambah, sehingga peserta dapat mengikuti kegiatan pelatihan dengan lebih maksimal.

\section{UCAPAN TERIMA KASIH}

Penulis mengucapkan terima kasih kepada Universitas Nahdlatul Ulama Purwokerto yang telah memberikan dukungan terhadap kegiatan pengabdian ini melalui program Hibah PKM oleh LPPM Universitas Nahdlatul Ulama Purwokerto.

\section{DAFTAR PUSTAKA}

Ahmadi, Muslim. (2009). Kumpulan Percakapan dalam Bahasa Inggris. Blogger Template: Webnolia

Arikunto, Suharsimi. 2010. Dasar-dasar Evaluasi Pendidikan Ed.Revisi. Jakarta: PT Bumi Aksara

Bailey, K. (2005). Practical English Language Teaching: Speaking. New York: McGraw-Hill.

Benlahcene, A., Lashari, S. A., Lashari, T. A., Shehzad, M. W., \& Deli, W. (2020). Exploring the perception of students using student-centered learning approach in a Malaysian public university. International Journal of Higher Education, 9(I). https://doi.org/I 0.5430/ijhe.v9n I 204

Brown, H.D., 2000. Principles of language learning and teaching. Addison WesleyLongman. Inc.[AC

Chao, C., \& Fan, S. (2020). The Effects of Integrating Board Games into Ice-breaking Activities in a Fifth-Grade English Class to Reduce Students' Anxieties. English Language Teaching, I3(9). https://doi.org//0.5539/elt.v13n9p40

Comrie, Bernard. 2009. The World's Major Languages. New York: Routledgeis Taylor and Francis.

Crocker, M. (2019). The Importance of Evaluation and Testing in an Educational System. International TEFL 
Pelatihan English Conversation Bagi Tenaga Pendidik di Universitas Nahdlatul Ulama Purwokerto

M. Happy Nur Tsani, Asfi Aniuranti, Asep Budiman

Vol. 1, No. 2, Agustus 2021 hal. 156-164

DOI Artikel : 10.46306/jub.v1i2.31

and TESOL Training.

Budiman, Arief. (2003). Basic English Conversation. Pustaka Grafika: Bandung

Hismanoglu, M. 2000. Language Learning Strategies in Foreign Language Learning and Teaching. The Internet TESL Journal. (online), Vol. VI, No. 8, August 2000 http://iteslj.org/, diakses tanggal 2 Nopember 2013

Gurley, L. E. (2018). Educators' preparation to teach, perceived teaching presence, and perceived teaching presence behaviors in blended and online learning environments. Online Learning Journal, 22(2). https://doi.org// 0.24059/olj.v22i2.1255

Ihsan, M. D. (2020). The Application of Presentation Practice Production Method for Teaching Speaking Skill: The Perception of Teachers and Students. Jurnal Inspirasi Pendidikan, IO(I). https://doi.org/l0.21067/jip.v10il.3854

Lie, A. (2017). English as a Lingua Franca: Implications for Pedagogy and Assessment. TEFLIN Journal, 28(I), $7 \mathrm{I}-92$.

Nation, P. (2017). Fluency Practice in the Four Skills. The 15th Asia TEFL \& 64th TEFLIN International Conference: Program Book.

Pasaribu, Berton. (2007). English Grammar for Zamil Training. Internal Use in BBPLKLN Cevest: Bekasi.

Paisley, V. (202I). 5 Reasons Why Conversation Practice Is Key to Learning a Language. Acceded at https://insights.learnlight.com/en/articles/conversation-practice-is-key-to-learning-a-language/

Patel, M. F., \& Jain, P. M. (2008). English Language Teaching (Methods, Tools, and Techniques). Jaipur: Sunrise Publisher \& Distributors.

Richards, J., C. \& Long, M.N. (1986). Breakthrough - A Course in English Communication Practice. Hong Kong: Oxford University Press.

Reddy, M.Samanth. 2016. Importance of English language in today's world. International Journal of Academic Research, Volume 3, Issue 4(2): 179-184.

Simamora, H, (2006). Manajemen Sumber Daya Manusia, Penerbit STIE YKPN, Yogyakarta.

Winardi, 2007, Motivasi dan Pemotivasian Dalam Manajemen Sumber Daya Manusia, Jakarta : PT Raja Grasindo Persada 